\title{
Conservative treatment of Boerhaave's syndrome in an octogenarian complicated with late distal esophageal stenosis and successfully treated by stent placement
}

\author{
Tratamiento conservador del síndrome de Boerhaave en un octogenario complicado con \\ estenosis esofágica distal tardía y tratado con éxito mediante colocación de stent
}

Orestis Ioannidis*, Anastasia Malliora, Panagiotis Christidis, Efstathios Kotidis, Manousos G. Pramateftakis, Ioannis Mantzoros, Nikolaos Ouzounidis, Vasilis Foutsitzis, Stamatios Angelopoulos, and Konstantinos Tsalis

Department of Surgery, School of Medicine, Aristotle University of Thessaloniki, Thessaloniki, Greece

\begin{abstract}
An 83-year-old female patient presented to the Emergency Department with shortness of breath, difficulty swallowing and leftsided chest pain following a vomiting attempt. A rupture in the left lower third of the esophagus, with hydropneumothorax, pneumomediastinum, and subcutaneous emphysema was revealed by chest $X$-ray, thoracic computed tomography scan, and contrast esophagography. The patient was successfully treated conservatively with closed thoracostomy, intravenous fluids, parenteral nutrition, and broad-spectrum antibiotics coverage. Following the successful conservative treatment, the patient developed a distal esophageal stenosis which was treated with an intra-esophageal self-expanding stent.
\end{abstract}

Key words: Esophagus. Spontaneous rupture. Esophageal rupture. Esophageal tear. Esophageal perforation. Boerhaave's syndrome.

\section{Resumen}

Una paciente de 83 años acudió al Servicio de Urgencias con disnea, dificultad para tragar y dolor en el lado izquierdo del pecho tras un intento de vómito. Una rotura en el tercio inferior izquierdo del esófago, con hidroneumotórax, neumomediastino y enfisema subcutáneo fue revelada por radiografía de tórax, tomografía computarizada de tórax y esofagografía con contraste. El paciente fue tratado con éxito de manera conservadora con toracostomía cerrada, líquidos intravenosos, nutrición parenteral y cobertura de antibióticos de amplio espectro. Tras el exitoso tratamiento conservador, el paciente desarrolló una estenosis esofágica distal que fue tratada con un stent autoexpandible intraesofágico.

Palabras clave: Esófago. Ruptura espontánea. Ruptura esofágica. Desgarro esofágico. Perforación esofágica. Síndrome de boerhaave.

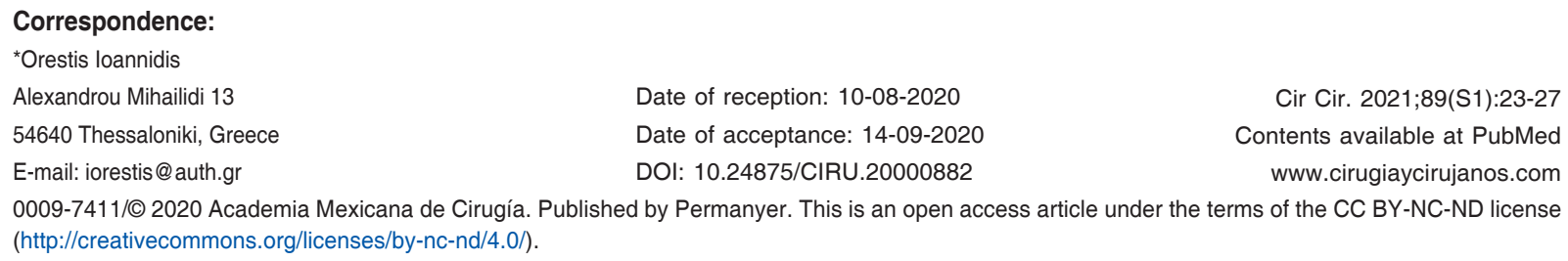




\section{Introduction}

Boerhaave's syndrome or spontaneous esophageal perforation is an uncommon but potentially fatal condition, as it may lead to severe mediastinitis, sepsis, and consequently multiple organ failure ${ }^{1}$. It usually manifests in adult (40-60 years old) ${ }^{2}$ alcoholic male patients ${ }^{3}$. Its symptoms are usually non typical, while the Mackler triad with vomiting, chest pain, and subcutaneous emphysema is found in $<33 \%$ of the cases ${ }^{1,4}$. Treatment can be surgical or conservative ${ }^{5}$. We present the successful conservative treatment of Boerhaave's syndrome in an 83-year-old female patient.

\section{Case report}

An 83-year-old female patient presented to the Emergency Department $15 \mathrm{~h}$ after the sudden onset of leftsided chest pain immediately after a vomiting attempt. She experienced shortness of breath, tachypnea, and difficulty swallowing. She was hemodynamically stable (blood pressure $=125 / 80 \mathrm{mmHg}$ and heart rate $=89$ pulses $/ \mathrm{min}$ ). Oxygen saturation was $92 \%$ and temperature $37.3^{\circ} \mathrm{C}$. Physical examination of the abdomen was normal, bowel sounds were normal, whereas thoracic examination revealed decreased breath sounds in the lower left lobe and crepitus consistent with subcutaneous emphysema. Blood test results revealed slightly elevated white blood cells and C-reactive protein, while the rest biochemical exams and electrocardiogram were normal. She underwent a chest X-ray, which revealed pneumomediastinum and hydropneumothorax and subcutaneous emphysema of the left hemithorax.

A chest tube was inserted under local anesthesia to drain the hydropneumothorax and the patient was submitted to a computed tomography (CT) scan of the chest and abdomen which also demonstrated the same findings of pneumomediastinum and hydropneumothorax and subcutaneous emphysema of the left hemithorax with no significant findings from the abdominal cavity (Fig. 1). A possible diagnosis of spontaneous esophageal rupture was considered which was confirmed with a gastrografin esophagography demonstrating a rupture in the left lower third of the esophagus (Fig. 2).

Based on patient's age, comorbidities, American Society of Anesthesiologists physical status score of III, anticipated morbidity and mortality of a surgical repair and time since the onset of symptoms $(24 \mathrm{~h}$ from the esophageal rupture after the definitive

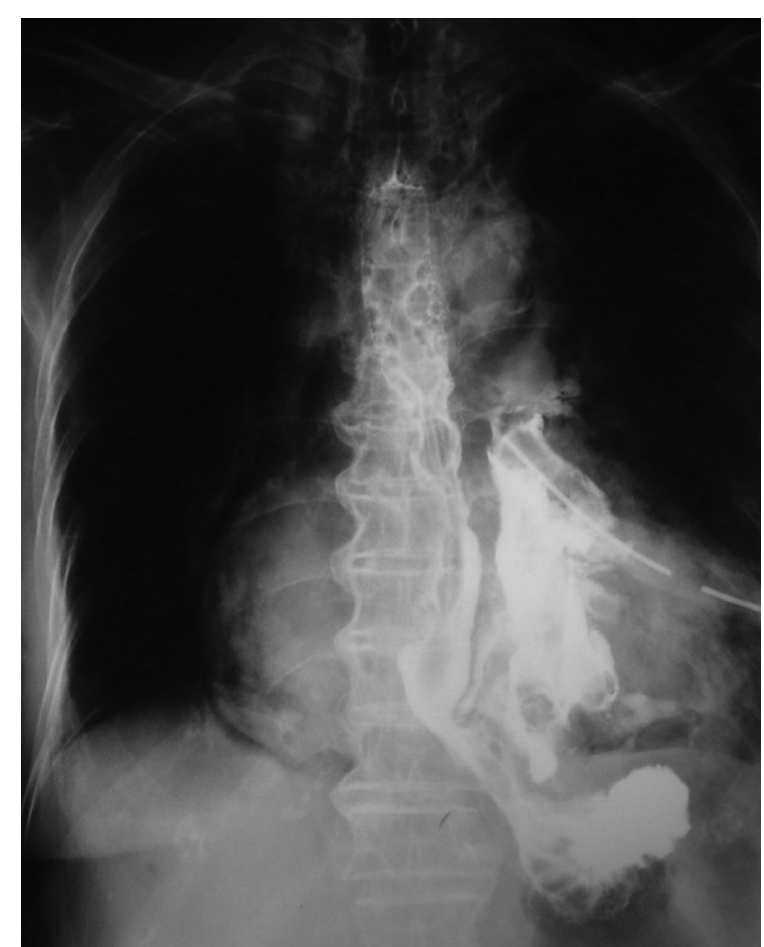

Figure 1. Gastrografin esophagography demonstrating a rupture in the left lower third of the esophagus and significant extravagation of gastrografin.

diagnosis) it was decided that the patient should be treated conservatively. Patient's hemodynamic stability and lack signs and symptoms of sepsis were also taken into consideration. Thus, except of the closed thoracostomy with one drain, the patient was kept null per os, while intravenous fluids, broad-spectrum antibiotics, and total parenteral nutrition were administrated. The patient continued to be monitored with clinical examination as well as laboratory and imaging tests, which revealed gradual improvement of her condition. On the $13^{\text {th }}$ day of hospitalization a gastrografin esophagography did not reveal any extravagation of gastrografin but demonstrated a stenosis of the distal esophagus (Fig. 3). As the next days, the patient was not able to eat and drink normally it was decided to place an intra-esophageal self-expanding stent which was successfully placed on the $30^{\text {th }}$ day of hospitalization and feeding began without problems (Fig. 4). She was discharged 3 days later.

\section{Discussion}

Boerhaave's syndrome or spontaneous esophageal perforation was first reported by Dr Hermann Boerhaave 

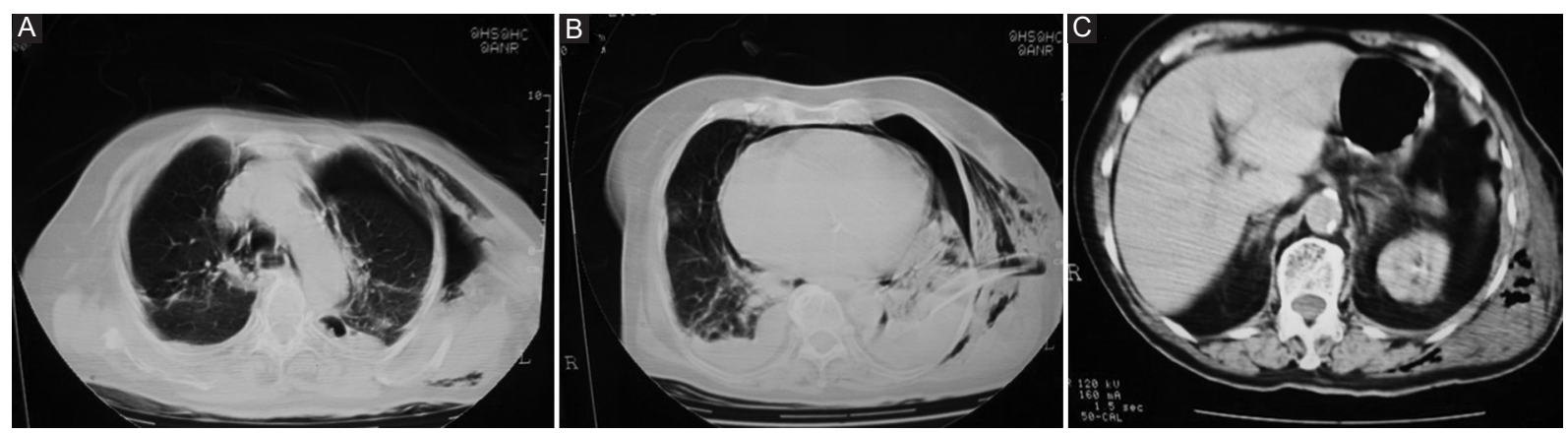

Figure 2. Thoracoabdominal computed tomography scan showing pneumothorax. A: pneumomediastinum and subcutaneous emphysema. B: hydropneumothorax, pneumomediastinum and subcutaneous emphysema. C: no significant findings from the abdomen except subcutaneous emphysema.

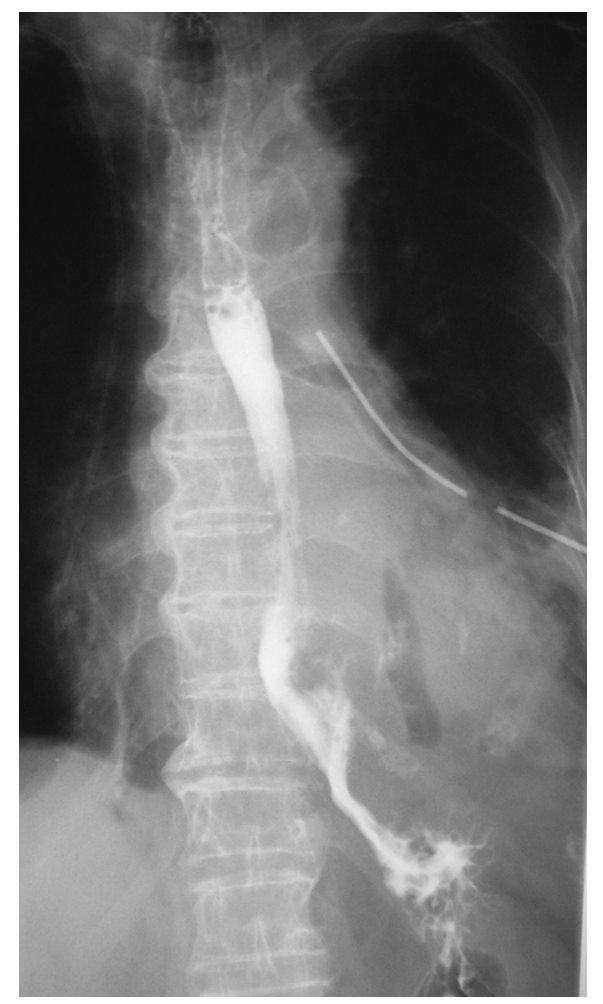

Figure 3. Gastrografin esophagography on the $13^{\text {th }}$ day of hospitalization showing no extravagation of gastrografin but distal esophageal stenosis.

in 1724. It is an uncommon but potentially fatal condition, as it may lead to severe mediastinitis, sepsis and multiple organ failure'. It has a significant high mortality rate that ranges between $20 \%$ and $75 \%$ and approaches $100 \%$ in untreated cases $^{7}$. Since delayed diagnosis and therefore treatment increases morbidity and mortality ${ }^{5}$ (delay of $12 \mathrm{~h}-36 \%$ and delay of $24 \mathrm{~h}-64 \%)^{3}$, the suspected cases should be identified and further investigated immediately.
Boerhaave's syndrome is usually manifested in adult (40-60 years old) ${ }^{2}$ alcoholic male patients ${ }^{3}$. Our 83-year-old female patient is an exception. Its etiology is the increased intra-luminal pressure in the esophagus, which mainly happens during vomiting ( $>95 \%$ of cases), as was in our case. Other rare causes are asthma, seizures, and childbirth, which also increase the intra-abdominal pressure. Esophagus lacks serosal layer that acts protectively, making it prone to rupture $^{2,8}$. The location of rupture is mainly in the left lower third of the esophagus ${ }^{7}$, as was in our patient.

Boerhaave's syndrome is misdiagnosed frequently. The clinical presentation of the syndrome varies from lack of symptoms to hemodynamic instability ${ }^{2}$ and may mimic other cardiothoracic or upper gastrointestinal diseases such as peptic ulcer perforation, myocardial infarction and pneumonia that are more common. Its presenting symptoms (vomiting and epigastric pain) are usually non typical ${ }^{1}$, while the Mackler triad with vomiting, chest pain, and subcutaneous emphysema is found in $<33 \%$ of the cases ${ }^{4}$. In late presentation (24 h) odynophagia, subcutaneous emphysema and Hamman sign (a "mediastinal crunch") ${ }^{9}$ can be found ${ }^{7}$. It has also been claimed that pain worsens with swallowing ${ }^{10}$ and it may be accompanied by dysphagia or fever ${ }^{4}$. Our patient experienced many of the typical symptoms.

The diagnostic tools for Boerhaave's syndrome are chest X-ray, contrast esophagography, esophagoscopy, and thoracic CT scan ${ }^{1}$. More specifically, chest X-ray may reveal hydropneumothorax, pneumothorax, pneumomediastinum, pleural effusion, subcutaneous emphysema, or widened mediastinum ${ }^{2,5}$, while contrast esophagography may show contrast media extravasation ${ }^{11}$ and is considered to be the gold standard ${ }^{12}$. Esophagoscopy is as sensitive as esophagography, but it needs to be carefully 


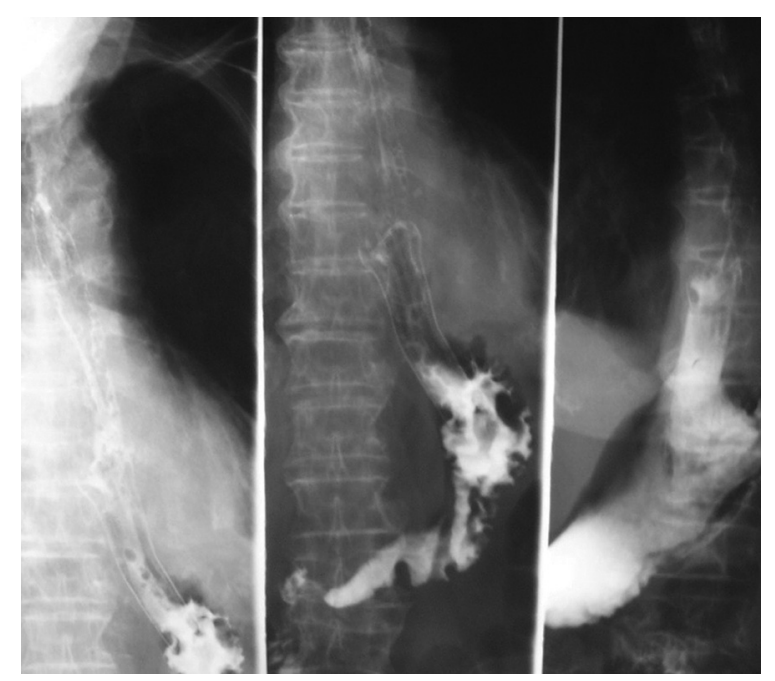

Figure 4. Gastrografin esophagography on the $30^{\text {th }}$ day of hospitalization after successful esophageal stent placement.

performed. Finally, CT scan may show pneumothorax, pneumomediastinum, and pleural effusion ${ }^{1}$.

Treatment of Boerhaave's syndrome remains controversial. Many authors argue that immediate surgery is necessary, whereas others support that if certain criteria such as early detection and limited to the mediastinum esophageal rupture, well drained cavity into the esophagus and limited patient symptoms without signs of sepsis and patient's stability, or pleural loculus esophageal ruptures are met, conservative treatment should be chosen ${ }^{1}$. It is most commonly believed that surgery should be the treatment of choice with a 2-layer primary buttressed repair and drainage of the pleural cavity ${ }^{1,13}$. Other suggests that the choice of surgical or conservative treatment should be based on the site and extent of the rupture, the patient's symptoms, signs, and radiographic findings ${ }^{5}$. Conservative treatment includes parenteral nutrition, broadspectrum antibiotics coverage, thoracostomy, and percutaneous drainage of fluid collections and has been proved to be efficient ${ }^{1,3}$. A $92 \%$ survival rate has been reported using these measures ${ }^{3}$. Endoprostheses, endoscopic management, clipping, and gluing have been also suggested ${ }^{4}$. The use of esophageal stents and percutaneous thoracic drainage in the treatment of Boerhaave's syndrome has not been well reported $^{14,15}$. However, esophageal self-expanding stents have been used and encouraging results have been reported, such as in a 2010 report, in which 10/15 patients were successfully treated with stent ${ }^{16}$. Over time new stents with improved properties, such as easier removal, have been invented. For instance, the recently invented Polyflex stent is suitable for temporary placement in benign conditions, can be easily removed and causes minimal tissue hyperplasia. In a few cases stents have caused complications, such as fistulas and strictures ${ }^{15}$.

A complication of conservative treatment that has been seldom reported in the literature is esophageal stenosis ${ }^{17}$. Stenosis can be successfully treated with endoscopic placement of an esophageal self-expanding stent ${ }^{17}$. In our case, spontaneous esophageal perforation was successfully treated in an octogenarian with conservative management (intravenous fluids and parenteral nutrition, broad-spectrum antibiotics coverage, and drainage) and after patient stabilization an esophageal stent was placed to treat the stenosis that has developed.

In conclusion, although Boerhaave's syndrome is a rare condition, doctors should be alerted to diagnose and treat it in time, so the patient could have increased chances of survival. Conservative treatment is an option for stable patients.

\section{Funding}

The authors declare no funding was received for the present study.

\section{Conflicts of interest}

The authors declare no competing financial interests or conflicts of interest.

\section{Ethical disclosures}

Protection of human and animal subjects. The authors declare that no experiments were performed on humans or animals for this study.

Confidentiality of data. The authors declare that they have followed the protocols of their work center on the publication of patient data.

Right to privacy and informed consent. The authors have obtained the written informed consent of the patients or subjects mentioned in the article. The corresponding author is in possession of this document.

\section{References}

1. Matsuda A, Miyashita M, Sasajima K, Nomura T, Makino H, Matsutani T, et al. Boerhaave syndrome treated conservatively following early endoscopic diagnosis: a case report. J Nippon Med Sch. 2006;73:341-5.

2. Kundra M, Yousaf S, Maqbool S, Mahajan PV. Boerhaave syndrome--unusual cause of chest pain. Pediatr Emerg Care. 2007;23:489-91. 


\section{O. Ioannidis, et al.: Conservative treatment of Boerhaave's syndrome}

3. Lee TC, Dreyer ZE, Brandt ML. Conservative surgical treatment of a profoundly immunosuppressed pediatric patient with Boerhaave syndrome. J Pediatr Hematol Oncol. 2005;27:616-7.

4. Chirica M, Champault A, Dray X, Sulpice L, Munoz-Bongrand N Sarfati E, et al. Esophageal perforations. J Visc Surg. 2010;147:e117-28.

5. Tsalis K, Blouhos K, Kapetanos D, Kontakiotis T, Lazaridis C. Conservative management for an esophageal perforation in a patient presented with delayed diagnosis: a case report review of the literature. Cases J. 2009;2:6784.

6. Wang Y, Zhang R, Zhou Y, Li X, Cheng Q, Wang Y, et al. Our experience on management of Boerhaave's syndrome with late presentation. Dis Esophagus. 2009;22:62-7.

7. Phelan HA, Brakenridge SC, Rutland TJ, Maltese C. Boerhaave syndrome presenting as massive hemothorax. South Med J. 2009;102:202-3.

8. Wilson DR, Cotie RW, Bailey LL. Boerhaave syndrome: lifters' liability. West J Med. 1980;133:517-9.

9. Curci JJ, Horman MJ. Boerhaave's syndrome: the importance of early diagnosis and treatment. Ann Surg. 1976;183:401-8.

10. Larrieu AJ, Kieffer R. Boerhaave syndrome: report of a case treated non-operatively. Ann Surg. 1975;181:452-4.
11. Rozycki GS. Image of the month. Esophageal perforation (Boerhaave syndrome). Arch Surg. 2001;136:355-6.

12. Teh E, Edwards J, Duffy J, Beggs D. Boerhaave's syndrome: a review of management and outcome. Interact Cardiovasc Thorac Surg. 2007;6:640-3

13. $\mathrm{Ng}$ CS, Mui WL, Yim AP. Barogenic esophageal rupture: boerhaave syndrome. Can J Surg. 2006;49:438-9.

14. Neff C, Lawson DW. Boerhaave syndrome: interventional radiologic management. AJR Am J Roentgenol. 1985;145:819-20.

15. Ghassemi KF, Rodriguez HJ, Vesga L, Stewart L, McQuaid KR, Shah JN. Endoscopic treatment of Boerhaave syndrome using a removable self-expandable plastic stent. J Clin Gastroenterol. 2007;41:863-4.

16. van Heel NC, Haringsma J, Spaander MC, Bruno MJ, Kuipers EJ. Shortterm esophageal stenting in the management of benign perforations. Am J Gastroenterol. 2010;105:1515-20.

17. Tsalis K, Vasiliadis K, Tsachalis T, Christoforidis E, Blouhos K, Betsis D. Management of Boerhaave's syndrome: report of three cases. J Gastrointestin Liver Dis. 2008;17:81-5. 